Fumio Kishi · Seitaro Fujishima - Mitsuaki Tabuchi

\title{
Dinucleotide repeat polymorphism in the third intron of the NRAMP2/DMT1
} gene

\begin{abstract}
Nramp1 (natural resistance-associated macrophage protein 1), encoding a polytropic integral membrane protein, was isolated as a candidate of the mouse Lsh/Ity/ $B c g$ locus, which regulates macrophage activation for antimicrobial activity against intracellular pathogens. The NRAMP2 gene was cloned from human genome as a homologue of NRAMP1. We found a polymorphic dinucleotide repeat in the third intron of the $N R A M P 2$ gene. This polymorphism will be a useful genetic marker to study disease associated with susceptibility to infection with intracellular pathogens.
\end{abstract}

Key words $N R A M P 2 \cdot D M T 1 \cdot$ Dinucleotide repeat $\cdot$ Iron transport

\section{Introduction}

In the mouse, natural (innate) resistance of the host to infection with intracellular pathogens such as Leishmania, Salmonella, and Mycobacterium is controlled by the Lsh/ Ity/Bcg locus. The Nramp1 (natural resistance-associated macrophage protein 1) gene was positionally cloned from the $L s h /$ Ity $/ B c g$ locus in the mouse genome (Vidal et al. 1993), revealing that the gene product has features characteristics of an integral membrane protein, including 12 putative transmembrane segments. Expression of the Nramp1 gene is controlled in a tissue-specific manner and is limited exclusively to phagocytic cells. The cDNA and genomic DNA for the corresponding human counterpart of Nramp1 were isolated and characterized (Kishi 1994; Kishi et al.

F. Kishi $(\bowtie) \cdot$ M. Tabuchi

Center for Gene Research, Yamaguchi University, 1-1-1 Minami-

Kogushi, Ube, Yamaguchi 755-8505, Japan

Tel. +81-836-22-2183; Fax +81-836-22-2185

e-mail: fkishi-ygc@umin.ac.jp

S. Fujishima

Department of Emergency and Critical Care Medicine, School of

Medicine, Keio University, Tokyo, Japan
1996). Afterward a second gene, $N R A M P 2$, was identified in the mouse and human genomes (Gruenheid et al. 1995; Kishi and Tabuchi 1997), and we isolated the human NRAMP2 gene and determined the complete DNA sequence, which is approximately $42 \mathrm{~kb}$ in length, containing 17 exons (GenBank accession number AB015355) (Kishi and Tabuchi 1998). Gunshin et al. (1997) electrophysiologically identified a rat divalent metal transporter, $D M T 1$, and found it to be an isoform of Nramp2. Nramp2/DMT1 exihibits an unusually broad substrate range, including $\mathrm{Fe}^{2+}$, $\mathrm{Zn}^{2+}, \mathrm{Mn}^{2+}, \mathrm{Cu}^{2+}, \mathrm{Cd}^{2+}, \mathrm{Co}^{2+}, \mathrm{Ni}^{2+}$, and $\mathrm{Pb}^{2+}$, and mediates active proton-coupled transport. The functional characteristics of NRAMP1 and NRAMP2 were determined by expression in a divalent metal transporter-disrupted strain of yeast cells (Tabuchi et al. 1999). Therefore a better understanding of genes responding to infection with intracellular pathogens as well as of divalent metal transport in the cells is important from the biological and the clinical points of view. To investigate the relationship between genetic variations at the NRAMP2/DMT1 locus and the host susceptibility to infections with various ferrophilic intracellular pathogens, including several Mycobacteria species, we characterized a polymorphic microsatellite in the NRAMP2/ DMT1 gene.

\section{Source and description}

A sequence of a microsatellite was identified in the third intron of the NRAMP2 gene through genome sequence analysis. Both the TA and CA repeats appear to be polymorphic. Polymerase chain reaction (PCR) primers were designed to amplify a fragment containing the dinucleotide repeat region.

PCR primer sequence

Forward: 5'-GTTCAGCAGCCTCAGGTTTAAT-3'

Reverse: 5'-CTATGGTTGTGCCACTGCACT-3' 
Fig. 1. A Nucleotide sequence of the polymorphic repeat and the flanking region of allele 3 at the natural resistance-associated macrophage protein $2(N R A M P 2) / \mathrm{di}-$ valent metal transporter $1(D M T 1)$ locus. Sequences used for forward and reverse primers are underlined. B Infrared fluorescence image showing a polymorphic repeat at the NRAMP2 locus in ten unrelated individuals
A

GTTCAGCAGC CTCAGGTTTA ATTTTGGCTG GCAATCTCTG AAGACTATAT CTATATATCT ATATATATAT ATACACACAC ACACACACAC ACACACCCCA TCTATATCTA TCTATCTCTG TCTGTCTGTC TGTCTGTCCG TCTATATATC TATCTATCTA TCTATCTATC TGTCTATCTA ATCTTTTTTA CAGACAGGGT CTTGCTCTGT CATCTAGGCT CCAGTGCAGT GGCACAACCA TAG
B

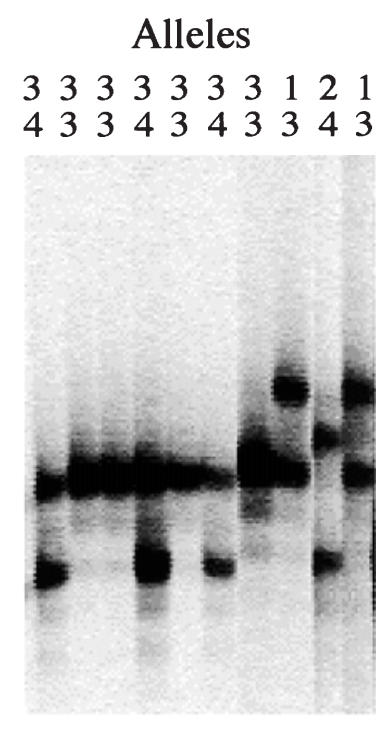

PCR conditions

PCR was performed in 7.5- $\mu$ l volumes of a mixture containing $50 \mathrm{ng}$ of genomic DNA, 1 unit of KOD Dash DNA polymerase (Toyobo, Osaka, Japan), $1 \times$ PCR buffer $\left(120 \mathrm{mM}\right.$ Tris $\mathrm{HCl}[\mathrm{pH} 8.8], 10 \mathrm{mM} \mathrm{KCl}, 6 \mathrm{mM}\left(\mathrm{NH}_{4}\right)_{2} \mathrm{SO}_{4}$, $0.1 \%$ Triton $\mathrm{X}-100,10 \mu \mathrm{g} / \mathrm{ml}$ bovine serum albumin, $1.25 \mathrm{mM}$ each of deoxyribonucleotide triphosphate [dNTP]s, $\quad 2.5 \mathrm{mM} \quad \mathrm{MgCl}_{2}$ ), $0.5 \mathrm{pmol}$ of an infrared fluorescence-labeled forward primer, and $0.5 \mathrm{pmol}$ of nonfluorescence reverse primer. The cycle conditions were $95^{\circ} \mathrm{C}$ for $2 \mathrm{~min}$, and then 35 cycles of $95^{\circ} \mathrm{C}$ for $1 \mathrm{~min}, 55^{\circ} \mathrm{C}$ for $1 \mathrm{~min}$, and $72^{\circ} \mathrm{C}$ for $2 \mathrm{~min}$, with a final extension step of $7 \mathrm{~min}$ at $72^{\circ} \mathrm{C}$, in a GeneAmp 9600 thermocycler (Perkin Elmer Cetus, Foster City, CA, USA). The PCR products were electrophoresed in 0.25 -mm-thick denaturing $7 \%$ polyacrylamide gels at $1500 \mathrm{~V}$ for $1-2 \mathrm{~h}$, using a LI-COR $4000 \mathrm{~L}$ automated DNA sequencing apparatus (LI-COR, Lincoln, NE, USA). The sizes of the alleles were determined by comparison with a sequencing ladder of a control plasmid.

\section{Polymorphism and allele frequency}

Frequency. Four alleles were detected in 140 chromosomes of DNA from 70 unrelated Japanese individuals (Table 1).
Table 1. Size and frequency of the alleles of the polymorphic microsatellite from genomic DNA of 70 unrelated Japanese individuals

\begin{tabular}{lll}
\hline Allele & Size (bp) & Frequency \\
\hline 1 & 247 & 0.014 \\
2 & 245 & 0.021 \\
3 & 243 & 0.743 \\
4 & 239 & 0.221 \\
\hline
\end{tabular}

A representative infrared fluorescence image of the repeat polymorphism is shown in Fig. 1A. The observed frequency of heterozygotes was 0.45 .

Mendelian inheritance. Codominant inheritance was observed in three two-generation families.

Chromosomal localization. The NRAMP2 gene was localized to chromosome 12q13 (Vidal et al. 1995).

Acknowledgments This work was supported in part by a grant from the Ministry of Education, Culture, Sports, and Science of Japan. 
References

Gruenheid S, Cellier M, Vidal S, Gros P (1995) Identification and characterization of a second mouse Nramp gene. Genomics 25: 514 525

Gunshin H, Mackenzie B, Berger UV, Gunshin Y, Romero MF, Boron WF, Nussberger S, Gollan JL, Hediger MA (1997) Cloning and characterization of a mammalian proton-coupled metal-ion transporter. Nature 388: 482-488

Kishi F (1994) Isolation and characterization of human NRAMP cDNA. Biochem Biophys Res Commun 204: 1074-1080

Kishi F, Tabuchi M (1997) Complete nucleotide sequence of human NRAMP2 cDNA. Mol Immunol 34: 839-842
Kishi F, Tabuchi M (1998) Human natural resistance-associated macrophage protein 2: gene cloning and protein identification. Biochem Biophys Res Commun 251: 775-783

Kishi F, Tanizawa Y, Nobumoto M (1996) Structural analysis of human natural resistance-associated macrophage protein 1 promoter. Mol Immunol 33: 265-268

Tabuchi M, Yoshida T, Takegawa K, Kishi F (1999) Functional analysis of the human NRAMP family expressed in fission yeast. Biochem $\mathbf{J}$ (in press)

Vidal M, Belouchi AM, Cellier M, Beatty B, Gros P (1995) Cloning and characterization of a second human NRAMP gene on chromosome 12q13. Mamm Genome 5: 224-230

Vidal SM, Malo D, Vogan K, Skamene E, Gros P (1993) Natural resistance to infection with intracellular parasites: isolation of a candidate for Bcg. Cell 73: 469-485 